\title{
Latin Down Under: Latin American migrant musicians in Australia and New Zealand
}

\author{
DAN BENDRUPS
}

Queensland Conservatorium, Griffith University, Brisbane, Australia

E-mail:d.bendrups@griffith.edu.au

\begin{abstract}
The global significance of Latin American popular music is well documented in contemporary research. Less is known about Latin American music and musicians in Australia and New Zealand (collectively termed 'Australasia'): nations that have historically hosted waves of migrants from the Americas, and which are also strongly influenced by globalised US popular music culture. This article presents an overview of Latin American music in Australasia, drawing on ethnographic research, with the aim of providing a historical framework for the understanding of this music in the Australasian context. It begins with an explanation of the early 20th-century conceptualisation of 'Latin' in Australasia, and an investigation into how this abstract cultural construction affected performance opportunities for Latino/a migrants who began to arrive en masse from the 1970s onwards. It then discusses the performance practices that were most successfully recreated by Latin American musicians in Australia and New Zealand, especially 'Andean' folkloric music, and 'tropical' dance music. With reference to prominent individuals and ensembles, this article demonstrates how Andean and tropical performance practices have developed over the course of the last 30 years, and articulates the enduring importance of Latin American music and musicians within Australasian popular music culture.
\end{abstract}

\section{Introduction}

In November 2009, Melbourne's Johnson Street Fiesta celebrated its 31st incarnation, making it one of the longest-running Spanish-speaking migrant community events in Australasia. ${ }^{1}$ Ten years previously, I had participated in this festival as a trombonist in various salsa bands that performed on open air stages set up at either end of the strip of Spanish and Latin American retailers, bars and clubs that line a single block of this inner-city street. ${ }^{2}$ In 2009 the daytime stage was handed over to local Latin dance teachers, who assembled the festival patrons into neat pairs for beginners couples' dances, stretching back along the centre of the road and observed on either side by those too shy or in too much of a hurry to join in. The amplified voice of a lithe male instructor conveyed directions in a smooth Latin-tinged English accent over pre-recorded dance soundtracks, while his lycra-clad female partner obediently demonstrated, with effortless grace, the dance moves approximated by the enthusiastic crowd below. 
A sudden deluge of rain forced spectators into the cavernous function room of Johnson Street's Hogar Español (a Spanish community club that has long hosted Latin American community events) where amateur flamenco dancers and a young singer-songwriter were providing the afternoon entertainment. I ran into Peruvian sonero Gualberto Casas, director of local salsa band Orquesta del Barrio, at the bar, who greeted me enthusiastically even though some years had passed since I last played in his band. He invited me to sit in for a gig they had later that evening on the other side of town, in another bar on St Kilda's trendy Acland Street.

Where the Orquesta del Barrio line-up of the 1990s had comprised up to 14 musicians, the 2009 version was a more streamlined septet, which included an expert freelance jazz pianist, a skilled trombonist straight out of jazz school in Perth, and a core of musically untrained Australian-born Latino percussionists who were learning the intricacies of salsa rhythms under Casas' watchful guidance. The audience comprised mainly young urban professionals who had chosen this bar as their meeting place for the night and had positioned themselves near the building's front balcony, far away from the band. Pressed up against the stage, four middle-aged Latin American men drank, danced with imaginary dance partners, and sang along throughout the evening. One of them, it transpired, was returning to Colombia after more than a quarter of a century living in Australia, and he was thrilled to hear his favourite local band one last time before he departed, drunkenly toasting them as 'lo major que hay fuera de Nueva York' ('the best, outside of New York'), or words to that effect. Melbourne, city of over three million inhabitants, is both geographically and culturally far removed from the Latin scenes of New York past and present, yet this drunken appraisal articulated one very important commonality between these distant and contrasting cosmopolitan centres: the signifying power of music as an expression of diasporic Latino/a identity.

In academic discourse, the translocation of music between Latin America and Africa (Manuel 1995; Wade 1998; Shain 2002), within European diasporic contexts (Eisentraut 2001; Román-Velázquez 2002) and to and from the USA (Salazar 2002; Pacini Hernandez 2010) has attracted considerable scholarly attention. Less consideration has been given to the extent of Latin American musical influence beyond these trans-American and trans-Atlantic routes. With some notable exceptions (Hosokawa 1999, 2002), the Asia-Pacific region does not feature prominently in Latin American music scholarship, yet the establishment of sizeable Latin American migrant communities in Australasia from the 1970s onwards has led to the creation of localised Latin music scenes which deserve consideration within the broader scope of Latin American music scholarship.

Theoretical constructs of transnationalism and cultural hybridity have an important place in the study of Latin American music diaspora. In the introduction to their seminal text, Aparicio and Jáques (2003, p. 4) identify transnationalism as a means of foregrounding '... the ideological tensions underlying the circulation of cultures [in the Americas], teasing out the simultaneous hegemonic and oppositional forces embedded in these dislocations', in other words, as a way of moving past reductive definitions of musical style according to static notions of nationality, ethnicity or social class. Furthermore, as Pacini Hernandez observes, the advent of late 20th-century globalisation has provided musicians with access to new international markets, and that the expansion of 'world music' as a market category has '... challenged the assumed purity and boundedness of musical categories that have long been taken for granted' (Pacini Hernandez 2003, p. 13), thus necessitating a 
transnational approach. More recently, Pacini Hernandez's discussion of hybridity and identity provides an essential examination of the place of Latino/a music and musicians within US popular culture (and, by extension, international consumers of US popular culture), revealing their '... unstable location in an industry that has insisted on defining and containing musicians and audiences within unambiguous racial and ethnic categories' (Pacini Hernandez 2010, p. 13).

While these theories are essential to the understanding of trans-American musical developments (especially with regard to the role of US popular culture as an incubator and transmitter of Latino/a music), they do not necessarily articulate the experiences of Latin American migrant musicians in Australasia. Many of the early 1970s migrants to Australasia were refugees who, for political or economic reasons, were unable to return to or maintain contact with their homelands. Their participation in music performance was therefore predicated on the basis of two distinct but entwined forces: the collective need within the multinational Latin American migrant community for music to articulate a shared sense of cultural identity, and, conversely, the local mainstream reception of 'Latin' music as globalised commercial music (cf. Negus 1999, pp. 131-51), which provided commercial opportunities for migrant performers. Both of these forces had a reductive effect on musicians' ability and motivation to create new music, instead engendering the reproduction of known repertoire that catered to the social, cultural and aesthetic needs of each. Only since the turn of the 21st century have Latin American musicians in Australasia really begun to develop a unique creative voice, and this has largely been undertaken by new migrants or by Australian born and raised children of migrants who are unburdened by the politics of exile or economic hardship that underscored the experiences of their parents.

This article begins with an explanation of the social conceptualisation of 'Latin' music in early 20th century Australasia, linking this mediated construction to subsequent expectations of the Latino/a migrants who began to arrive from the 1970s onwards. It then discusses the performance practices that were most successfully recreated by Latin American migrant musicians in Australia and New Zealand, especially 'Andean' folkloric music, and 'tropical' dance music. ${ }^{3}$ With reference to prominent individuals and ensembles, this article demonstrates some of the ways in which Andean and tropical performance practices have developed over the course of the last 30 years, articulating the continuing relevance of this music to Australasian performance culture. ${ }^{4}$

While many non-Latino/as have also made crucial contributions to live Latin American music in Australasia, this article centres on the roles played by the migrant musicians who arguably gave (and give) the Australian and New Zealand scenes their unique character. More could be said about the local popularity of Latin American music styles within the contexts of social dancing, ballroom dancing and jazz performance. Other worthy research topics such as samba drumming, tango dancing or capoeira groups, in which a majority of non-Latino/as participate, or even the contribution of Latin American migrants and their descendants to classical, contemporary and rock music scenes, academia, commercial media and dance culture in Australasia provide grounds for further investigations that lie beyond the scope of this article. In anticipation of such investigations, this article provides a contextual framework for understanding the development of spaces for Latin American performers within the broader context of Australasian popular culture over the course of four decades from the 1970s onwards. 


\section{Latin American music in the Australasian context}

Long before the establishment of Latin American migrant communities in Australasia, externally projected cultural assumptions about Latin American music and dance provided local audiences with enduring preconceptions and expectations of popular Latin American performance. Historically, as has been observed with regard to the US, the gap in information concerning Latin America was often filled with fictitious representations in film and television (Woll 1980, p. v, in Clark 2002, p. 253). In the Australasian context, this extended to music and dance, much of which had already been recontexualised as middle-class entertainment for North American and European audiences before eventually reaching Australasia. According to Australian musicologist John Whiteoak, this began in 1913 with a tango craze that eventually led to the local publication of dance manuals and locally composed tangos:

The craze began with stage demonstrations - and humorous parody acts - of the greatly stylised versions of the Argentine tango that had just become popular in London, Paris and New York. Soon, at tango teas in ballrooms in Melbourne, Sydney and probably other capital cities the dance was demonstrated to guests, who then attempted it with their own partners. (Whiteoak 2003, p. 393)

In similar fashion, Latin elements in globalised ballroom and social dance in the 1920s and 1930s, in jazz repertoire of the 1930s and 1940s, and in Hollywood and Broadway productions in the 1940s and 1950s led to the local interpretation of Latin repertoire that had already become popular internationally. The surge in production of Latin-themed films in post-World War II USA (Clark 2002, p. 255) and the concurrent expansion of 'Hollywood Latin' in US popular culture (cf. Macías 2003, p. 184) also influenced the Pacific region, where thousands of US armed forces personnel were stationed during and after the war, providing local audiences with increased access to US entertainment industry goods. The development of New Zealand jazz, for example, owes a great deal to the unprecedented contact between New Zealanders and American armed forces musicians during and after World War II (Hardie and Thomas 2009, p. 7). While 1950s Australasian jazz scenes were not specifically oriented around a Latin-jazz repertoire, styles such as mambo and samba were occasionally used as the basis for local compositions (see Bendrups 2001, p. 22), but in a manner that treated them simply as genres within the aesthetically diverse jazz canon, disengaged from their Latino/a cultural roots.

A further complication for the representation of Latin music in Australia prior to World War II is that Latin American and Spanish music often appeared in the repertoire of popular 'continental' or 'Gypsy' bands. These ensembles of indeterminate ethnicity performed stylised representations of an exotic cultural other based on local 'imaginings and constructions' (Whiteoak 2008, p. 17) of Gypsy and/or non-Anglophone European folk repertoires, and their popularity extended well into the 1960s. As Whiteoak notes:

These hybrid stereotypes reached Australia primarily via the great success of costumed Gypsy-café style tango orchestras in London. These, which importantly included radio orchestras, were often led by leading dance band musicians who performed under Italian or Latino pseudonyms ... their costumes, backdrops, props and repertoire variously embrace [d] the Spanish, Hungarian and Russian 'Gypsy' and also the Argentine gaucho.... (Whiteoak 2008, p. 19) 
The 1950s expansion of US influence in Australasian popular music created a demand for Latin music at a time when the region still lacked sufficient expert performers from Latin America. This resulted in the consolidation of 'Latin' performance in communities and music scenes that did not necessarily have any affinity with Latin America. In Australia, for example, some Italian-Australian performers adopted Spanish or Spanish-sounding names in the 1950s and 1960s (Whiteoak 2009, p. 16) as a way of boosting their appeal within (and outside) the Italian-Australian community. In post-war New Zealand, Latin music was mainly consolidated as culturally decontextualised repertoire for headline entertainers and large-format ensembles catering for dance events, television and other types of massmediated performance. When large-scale Latin American migration to Australasia began in the 1970s, migrant musicians therefore encountered pre-conceived 'Latin' performance scenes, populated by non-Latino/a performers and possessing unique local histories and fan bases. These scenes provided easily accessible performance opportunities for Latino/a migrants, yet the localised conceptualisation of Latin as mass entertainment music also presented new migrants with artistic and cultural challenges, as only US-mediated performance genres like mambo or bossa nova were widely appreciated by local audiences.

\section{Latin American migrants in Australasia}

Large-scale Latin American migration to Australasia can be divided chronologically into two stages: 1970 to 2000, and 2000 to present. The first stage of migration was instigated by political and economic instability in South America (principally Chile, Argentina and Uruguay, and to a lesser extent Brazil) in the 1970s, and Peru, Colombia, Guatemala and El Salvador in the 1980s. Many of these migrants came seeking political asylum, and their experiences imbued local Latin American music making with both social and political consciousness. Others were economic refugees taking advantage of the Australian government's 'new immigration policy' to escape the poverty of and lack of opportunities offered by South America in the 1970s (Mayne 1989, p. 82). Many of the migrants who settled in New Zealand subsequently resettled in Australia, attracted by the larger and better established Latin American communities there.

The second stage was instigated by improved economic circumstances in Latin America after 2000, and the creation of new incentives for Latin American migrants to study and work in Australasia. This stage comprises mainly short-term migrants arriving on study visas or short-term work arrangements that became available post-2000 and, increasingly, spouses of expatriate Australians and New Zealanders returning to reside in Australasia. For the most part, these are young adults, many from middle-class backgrounds, who do not share the experiences of political oppression or economic hardship of the previous generation of migrants.

By 1991 the number of Latin Americans in Australia was about 49,700, or 0.2 per cent of the Australian population at that time (Ryan 1998, p. 82). With the return of democracy (and relative economic stability) to most of Latin America after 1991, the flow of Latin American migrants to Australia diminished. While comprising a relatively small proportion of the overall population, Latin Americans managed to maintain close-knit communities in Australian capital cities, thereby ensuring some degree of visibility in the mainstream. This visibility was greatly assisted by the 
mainstream popularity of Latin cultural festivals established in the late 1970s, as well as a general perception of Latin American culture as a source of mass entertainment. In most cases, first-generation Latin American migrants remained in the suburbs close to the immigration centres they arrived at, or within the public housing estates that many were allocated to. Later migrants from other Latin American countries were also attracted to the same suburbs because of their established Spanishspeaking communities (Burnley 2001, pp. 215-19).

Regardless of the social or professional position that they held before migrating, most first-stage Latin American migrants found themselves economically marginalised, initially offered only unskilled blue-collar employment and minimum wages (Burnley 2001, p. 215), and all were thrust into the unusual position of being perceived by the wider Australian society as a homogeneous social group because of their shared language. As Spanish speakers they were further associated with Spanish migrant communities, and the 'Spanish Clubs' of both Melbourne and Sydney became centres of Latin American cultural entertainment. This socio-cultural demarcation by the Anglo-European mainstream, combined with the difficulties faced by migrants in becoming accustomed to life in their host countries, encouraged migrants from many different (and sometimes antagonistic) Latin American countries to band together under the shared characteristics of language and culture. In this context music became an important marker of shared identity, with pan-Latino styles favoured over local or niche traditions. Prominent Melbournebased Chilean musician Alex Vargas states:

I think that we became more representative of our country after migration than we had ever been previously. I think that all migrant groups would say similar things about the need to communicate with each other and with outsiders through these kinds of performances. My father, for example, was thirty-eight when we came. At thirty-eight, you don't easily learn new things, let alone a new language. A week after he arrived, he had to go and work twelve hours a day in a factory to support the family, leaving him with little time to do anything else. His outlets were to watch the soccer, scream in his own language, and share a few drinks with others who understood him, who also had similar needs and outlets. You get more communication between people within the community, and we ended up mixing with people who, back in Chile, we would never have talked to. (Interview with the author, 14 December 2001)

As in Australia, migrants from Latin America were virtually unknown in New Zealand until the military coups of the 1970s forced thousands into political exile (Wilson 2009). From the outset, Latin American migrants engaged extensively with wider New Zealand society, leading to the participation of many New Zealanders in Latin American migrant music and dance. This engagement is a reflection of three factors: the extant popularity of Latin music in global commercial popular music, the interest of New Zealanders in participating in perceived exotic activities such as Latin dancing or (since the 1990s) samba drumming, and the willingness of local music industry gatekeepers to promote and support Latin American musicians and other performers of Latin American music through recording contracts and participation in prominent national and local festivals. The initial intake of Latin American refugees in the 1970s has been bolstered since 2000 through immigration policy changes that have made it easier for Latin Americans to obtain student and working-holiday visas for New Zealand. These population increases are evidenced in census data from 2001 and 2006 which reveal strong increases in the numbers of Brazilians, Chileans and Argentineans settling in New Zealand. ${ }^{5}$ In general, 
the small number of migrants from any particular country has engendered the formation of pan-Latino/a communities in major New Zealand cities, resulting in interesting musical collaborations between Brazilians, other Latin Americans and New Zealanders. Social dance groups play a significant role in the life of these communities, and the enthusiasm of key organisers has led to the development of strong ties with Latin American embassies in Wellington and even the creation of participant-oriented events like Jambalaya, a festival featuring a unique hybrid of Latin American and Pacific Island music and dance performance practices.

\section{Andean music}

The most prominent representation of the relationship between migration, politics and music for Latin Americans in Australia and New Zealand is the localisation of Andean folkloric music, which has become a permanent facet of street performance in capital cities throughout the region. Initiated predominantly by first-stage Chilean political exiles, the Andean ensembles that formed in the late 1970s drew on the model of charango, quena, zampoña, bombo and guitar instrumentation that became prominent in Chile in the 1960s, and which ultimately became associated with the rise of socialist candidate Salvador Allende to the Chilean presidency in 1969. As Jan Fairley notes, this performance format was itself modelled on that of Bolivian group Los Jairas, who became well known in Chile in the 1960s and were associates of prominent Chilean singer-songwriter Violetta Parra (Fairley 2000, p. 275).

The international political profile generated by the high-profile performance trajectories of Chilean folk-fusion ensembles Inti Illimani and Quilapayun, whose exile from Chile after the 1973 military coup positioned their music in opposition to the Pinochet regime (Fairley 1989, p. 4), also resonated in Australia, where socialist organisations and trade unions were among the strongest supporters of Andean musicians. The creation of Andean ensembles in Australia was largely instigated by Inti Illimani's 1977 tour, as Alex Vargas recalls:

We came here in 1975, after the coup. Members of my family had been involved with the previous government in various ways, and it was becoming hard for us to survive. We didn't know too much about it all as we were children ... my brother and I always played music, and we met Nancho, a flute player who had just arrived from Chile, in 1977, just the same time as Inti Illimani had their first tour to Australia. Following their tour, in June 1977, we formed Apurima - the first Andean group in Australia - in August. We were learning together, as we really knew nothing about Andean music. When we grew up in Chile, Andean still music wasn't that big, so we learned most of what we know here in Australia. (Interview with the author, 14 December 2001)

Vargas' musical efforts resembled those of other parts of the international Chilean diaspora, as exemplified by Paris-based group Karaxu (Fairley 1989), and as examined in the Norwegian context by Jan Knudsen (2001). This process of identity re-creation through music continued well into the 1980s. One of the longest-running folkloric groups in Australia, Arauco Libre, was formed in Hobart in 1987 by Chilean political exiles. The issue of political identity is paramount in the band's selfconceptualisation, as indicated on their website, which states:

The name of the band refers to the indigenous people who spread across southern Chile and Argentina, whose culture and language are suppressed by the larger governments in which the group live. Hence the band's name is a political statement - 'Freedom to the Araucanians'.6 
Curiously, while Arauco Libre perform with the instrumentation and musical style characteristic of urbanised Chilean and Bolivian Andean folklore, their band name references an indigenous community that is not at all Andean. The Araucan Mapuche were the only indigenous group of the cordillera region not to have come under the dominion of the Incas, and their music is very different from the Quechua and Aymara influences that underpin the model developed by Los Jairas. Nevertheless, the connotations of freedom and resistance that are associated with the long history of Araucan resistance to Incan, Spanish colonial and Chilean domination provide Arauco Libre with a vehicle for re-visioning their own political subjectivity.

Like other Andean groups, Arauco Libre rose to prominence through local community-focussed, open air performances. Alongside numerous appearances at regional folk festivals, they have been performing at Hobart's well-known Salamanca Market ${ }^{7}$ practically every weekend for more than 20 years. During this time, they have produced five commercial recordings which they sell at the market performances.

Despite the political context that gave rise to the creation of Andean performance troupes in exile, performers in Australia and New Zealand did not compose songs with overt political content, and their repertoire has tended more towards a transnational Southern-Cone folkloric aesthetic than a faithful representation of any particular national tradition (Díaz Gomez 2003, p. 395). The social activist associations of Andean performance have perhaps helped to steer Andean performers towards public performance spaces such as markets and folk festivals, but, after the initial period, these spaces were not explicitly determined by any particular political activism.

The end of the Pinochet dictatorship and the return of democracy in Chile after 1991 did not engender a decline in Andean music performance in Australasia. Rather, Andean performers adapted themselves to a 'world music' framework which emphasised indigeneity, rather than political protest. In the case of Arauco Libre, this has meant assuming a stance of representing indigenous Latin America and adopting indigeneity rather than political exile as a marker of subaltern identity. This stance is reflected in recordings dedicated to indigenous topics, such as their recent release Mapuche (2006) which is described as a recording that 'embodies the magic and mystery of our homeland and its people' ${ }^{8}$ None of the current band members is of Mapuche ethnicity, and the band includes Bolivian as well as Chilean musicians. It is the evocation of indigeneity, rather than a specific desire to play Mapuche music, that underscores this particular production, which carries on the pan-Andean and folkloric performance aesthetics of the group's previous recordings.

The diverse Chilean and Bolivian repertoires performed by Arauco Libre reflect the cultural heritage of band members who identify as being in some sense indigenous to these countries, and it is this evocation of their cultural identity that provides a way of connecting with mainstream Australia, where issues of indigenous politics occasionally saturate public discourse. By avoiding a political position based on ideology or exile experiences, Arauco Libre and other groups are also able to effectively incorporate second-generation performers. These Australian-born or raised children do not have the same experience of political exile that their parents faced, but they do have the experience of having to negotiate their own cultural identity in the Australian context, and can therefore appreciate the discursive space that the discourse of indigeneity offers. 
Prominent Melbourne group Inka Marka, established in 1997, epitomises the experience of second-generation engagement with Andean music. The current group members are the children of migrants who came to Australia in the 1970s. Most of them were infants when they arrived here, one was born here, and all have grown up as 'Australians'. Thus, they do not share the experience of dislocation described by Vargas. Rather, the musicians of Inka Marka see their Andean performances as a way of getting in touch with their shared Latin American cultural heritage. In the same way that Arauco Libre have no actual Araucan connections, the Peruvian-sounding Inka Marka is not actually a Peruvian (or for that matter Incan) band. They play the same repertoire as the previous generation of politically engaged Andean groups in Melbourne, but are quick to distance themselves from political representations. Feeling neither fully 'Latino' (due to growing up in Australia), nor fully 'Australian' (because their parents are migrants), Inka Marka emphasise the cultural links between their displaced selves and music described in the liner notes of their album Auki Auki (1999):

Auki Auki ... is a very spiritual piece of music which is supposed to embed itself in the subconscious after several listenings. You are then to imagine your link with the ancestors of the Aymara or Quechua people, themselves a bridge to the magnificent Inca culture.

Managed since 2001 by music industry insider Linda Drew, Inka Marka have achieved significant exposure through a nomination for 'best world music album' at the 14th Australian Recording Industry Association (ARIA) awards, and through their workshops for school music programmes. Indeed, the band has a comprehensive workshop curriculum that they advertise on their website, offering an introduction to Andean musical instruments, music and even lessons in Andean ethnomusicology. ${ }^{9}$

Lacking the extensive trade union and Chilean community networks of Australia, Andean performances in New Zealand were less frequent historically. Nevertheless, specialist musicians have been able to capitalise on the established regional practice of streetscape performance to promote Andean music in the New Zealand context, and these isolated performances often reflect unexpectedly deep, international music networks. The creation of a local WOMAD and other worldmusic oriented festivals in the 1990s also helped to provide opportunities for performers of Andean music to enter the New Zealand market. The most active of these performers is Tauranga-based ensemble Alymayu, led by Ecuadorian flautist Julio Ramirez. A musician of Imbaya heritage, Ramirez migrated to New Zealand in 2004 for family reunion purposes, and quickly established himself as a performer by undertaking extensive, lengthy busking tours of the country. As the traditional instrumentation of Andean music necessitates an ensemble of performers, Julio draws on a network of musicians and relatives living as far away as France and Germany to accompany him in these busking tours, and his recordings have also been produced via international industry channels in Germany and Peru. Alymayu's album Latitud '0 (2008) differs remarkably from Australian examples in that it avoids mass-mediated Chilean and Bolivian repertoire, instead presenting specifically Ecuadorian traditional repertoire and original compositions. Where Australian Andean ensembles are generally multi-ethnic and try to represent a range of Latin American performance traditions, Alymayu draw mainly on repertoire and performance practices from the Imbabura region of Ecuador, with only 
an occasional inclusion of pan-Andean repertoire made famous by Inti Illimani and others.

The perseverance of groups like Arauco Libre and the creation of new groups like Alymayu suggest that Andean music performance is a going concern for live music in Australasia. This perception is reinforced by the willingness of local institutions (such as the Salamanca and Queen Victoria markets) and commercial music festivals to provide spaces for Andean performance. Furthermore, performers of Andean music are not limited to Andean music genres in the Australasian context, as many also perform in tropical dance music contexts, as I will now discuss.

\section{Tropical dance music}

Tropical dance bands developed within the mass-mediated entertainment industry niche that previous generations of 'Latin-esque' performers created for Latin music in Australia and New Zealand. Initially, in the 1980s, these bands adhered to a limited range of music styles that could be used in dance contexts, particularly transnational globalised genres like salsa, cumbia and merengue. Other important Afro-Caribbean musical forms were not present in the repertoire of 1980s Latin bands in Australia and New Zealand, largely because they lay beyond the direct experience (and musical expertise) of the Southern Cone and Central American migrants who arrived here. Furthermore, some of the most active performers had little or no formal musical training prior to their arrival, and their performances were therefore somewhat approximated and based on the emulation of available recordings rather than on learned or inherited musical knowledge. These circumstances resulted in a local tropical music performance characteristic described by Mike Ryan as demonstrating a kind of 'reportorial standardisation' (Ryan 1998, p. 84), which has had both positive and negative consequences for performers of Latin American music. On the one hand, standardisation made music and dance participation accessible to most members of the Latin American migrant community, giving migrants the opportunity to participate in a strong and binding cultural activity without having to learn the very specialised and technically difficult skills of a professional musician or dancer. It also made the music successful with non-Latino/a audiences, because much of the repertoire featured songs and song styles that were widely available in the public domain. On the other hand, with covers far outnumbering original compositions, the repertoire and performance styles of many first-generation Latin bands became repetitive and stagnant. They played songs which were popular at the time the bands were put together (most of the large Latin dance bands were formed in the 1980s) and rarely expanded their repertoire to include new material. The exception to this was when a Latin song became popular in mainstream record charts, as was repeatedly the case with Latin 'crossover' artists after 1998 (cf. Cepeda 2000).

In some cases, bands opted for a covers repertoire for other reasons, such as the political or social significance of particular songs or performers. As Gualberto Casas, sonero and manager of Melbourne salsa group Orquesta del Barrio states, 'We started [in the early 1990s] performing salsa already known from recordings because this is what was popular [and because] people could identify with the sentiments expressed in these songs' (Interview with the author, 20 September 2009). The sentiments Casas refers to are epitomised by songs like 'El Ratón' with its multi-layered hidden 
meanings (Rondón 2008, p. 96) and a number of Rubén Blades compositions articulating a brand of social commentary that resonated with a pan-Latino/a audience of political exiles. One of the most interesting characteristics of this covers repertoire is that it enabled bands like Orquesta del Barrio to perform to entertainment seekers and political exiles simultaneously. In the 21st century, with political exile no longer an issue for most first-generation migrants, and in the wake of a revival of 'Golden Age' salsa by New York musicians such as Jimmy Bosch, the Fania covers repertoire has allowed groups like Orquesta del Barrio to further re-position themselves as 'Golden Age' salsa ensembles without having to make any substantial repertoire changes.

New Zealand's most commercially successful Latin group, Auckland-based Kantuta, established in 1983, provides a different example of community engagement through repertoire choices. Lacking the extended community of political exiles present in Australia, Kantuta aim their performances at a mainstream non-Latino/a audience, including highly mass-mediated songs such as 'La cucaracha' and 'Guantanamera' alongside their original compositions, which were mostly in the salsa romantica style, often with both Spanish and English lyrics. Kantuta was founded by Chilean brothers Alvaro and Eduardo Díaz who settled in New Zealand in the early 1980s after years of political exile in Peru. Initially, the group provided entertainment to patrons at the Díaz family's restaurant in Auckland. They adopted the name Kantuta (translated by the band as 'sacred flower of the Incas') as a way of articulating their connection to their homeland. The Díaz brothers were skilled performers of Andean flutes and other folkloric instruments, and the band originally performed a folkloric Andean repertoire. However, after 1989, they incorporated a multi-ethnic cast of musicians into the band and adapted their Andean instruments to play tropical styles that would be more appealing to a New Zealand audience. The band's development coincided with the global rise of the Gipsy Kings and their eponymous album (1987) in international markets, and Kantuta capitalised on this by including the iconic (and socio-culturally incongruent) rumba flamenca style among their own 'tropical' repertoire. This influence is evidenced in their debut album Kantuta (1992) where three of the 11 tracks are in a rumba flamenca style (other styles represented include merengue, samba and salsa). Kantuta earned the respect of audiences in both Auckland and Wellington, where they toured under the headline of 'Cultural Ambassadors' in 1991, and self-produced a cassette of original recordings which continually sold out. Eduardo Diaz and saxophonist Cameron McKenzie successfully negotiated a record contract with EMI New Zealand on the basis of their popularity with audiences in both cities. The ensuing eponymous album achieved double-platinum record sales in New Zealand. Later, Kantuta gained further prominence in the Auckland live music scene through their long residency at Auckland's SKYCITY Casino.

Given the scarcity of Latin American musicians in New Zealand as compared to Australia, Kantuta took advantage of opportunities to bring visiting musicians into their performances. In this way, they incorporated Colombian guitarist Hernan 'Chico' Zarate (in 1991) and noted Puerto Rican percussionist Miguel Fuentes (in 1992) into their line-up. Both Zarate and Fuentes eventually decided to settle in New Zealand and both continue to play with Kantuta, which in its current form is managed by Cameron McKenzie. The lack of sufficient financial support for live performance by large-scale bands has led Kantuta to incorporate sequenced percussion into their live performances alongside live percussion as a way of managing live 
performance budgets. They are not alone in this regard; other New Zealand-based performers such as Peruvian vocalist and leader of band Matecito, Gerardo Torres, also use sequencing, in some cases extending this to include brass and piano parts as well as percussion.

While Australian salsa bands were covering Fania recordings for their Latino/ a-inclusive audiences, Kantuta attempted to engage New Zealanders with covers of locally significant songs, such as the anthemic 'April Sun in Cuba', by the iconic New Zealand rock band, Dragon. While the original version of 'April Sun in Cuba' is a nostalgic rock song referencing a far-off unattainable paradise, Kantuta's version of this song exaggerates the referencing of Cuba as a nexus between their own Latino identity and the collective imaginings of wider New Zealand society by recontextualising the original lyrics against a chachacha song structure and adding Spanish interjections to the chorus.

Notwithstanding Kantuta's extensive catalogue of original compositions, like other 'tropical' Latin bands in Australasia, their performances have had to cater to the repertoire expectations of the mainstream to ensure their commercial sustainability. For example, their third studio album Fiesta: the Ultimate Latin Dance Album Salsa Merengue Dance Party (1997) contains stylistically incongruent cover repertoire such as 'El condor pasa' and even 'Zorba's Dance', which can only be conceived as 'Latin' in terms of the pan-European 'continental' ensemble tradition described by Whiteoak (2008). Similarly, in their studio album Party with La Cucaracha (1998), longstanding Melbourne Latin dance band Tropical Dreams includes songs such as 'La cucaracha', 'Feeling Hot, Hot Hot' and even James Brown's 'I Got You (I Feel Good)' alongside more obscure covers of Chilean cumbia.

It would be easy to dismiss these endeavours as commercial opportunism by their Latino producers, yet these repertoire selections also reflect the constraints that mainstream expectations unwittingly placed on migrant musicians trying to create a niche for themselves in Australasian markets in the 1980s and 1990s. In a recent conference paper, Sydney-based Chilean bassist and producer Waldo Garrido reflected on the barriers created by mainstream expectations of Latin music in relation to the production of an album that was conceived as a fusion of Latin and non-Latin music styles:

My efforts to create a style that would cross over and be accepted by both the Latin community and mainstream did not pay dividends commercially at least in Australia. As per the response of mainstream in Australia including the written media and radio stations, there was a positive initial reaction with great reviews [however] commercial stations were not willing to program the singles; as they found the songs to be 'too Latin'. Not even the remixed versions of the single, which the record company had attempted to anglicise, [reached] commercial radio. (Garrido 2009)

The situation for tropical music has changed considerably since the turn of the 21st century. Where first-generation bands tended towards a generic repertoire of danceable cover songs, often performed in an approximated style, second-generation performers and recent migrants have expanded the scope of popular Latin music performance to include more 'authentic' performances of localised styles, and even created a wealth of original compositions. On the one hand, this reflects a growing familiarity with Latin American music in the mass media, instigated by the Buena Vista Social Club phenomenon after 1998 (Wyndham and Read 2003) and subsequently reinforced through international tours by this and other 'cultural 
performance' ensembles. The interest in presumed 'accurate' or 'authentic' performance of perceived-traditional styles that the Buena Vista Social Club phenomenon generated among fans of Latin music increased the cultural capital of newly arrived Cuban performers in Australia and New Zealand, as well as that of non-Latino/as with perceived expertise in Afro-Cuban music. A good example is Christchurch salsa band Ritmo Latino, led by Canadian congosero Giles Nantel. Nantel studied bata in Cuba, and with Cuban percussionists in Canada, before migrating to New Zealand in 2001, where he is now among the foremost local authorities on Cuban percussion. While Nantel lacks the perceived authenticity of Latino ethnicity that many performers in Australasia rely on for their commercial survival, his expertise in percussion is valued by audiences that are becoming increasingly familiar with, and interested in, the intricacies of Afro-Cuban genres and their underpinning rhythmic constructs.

Since 2003, the New Zealand capital city of Wellington has developed a thriving live Latin American music scene, largely due to the arrival of a handful of migrant musicians from Mexico and Cuba. There is a history of interest in Latin music among musicians in the Wellington jazz scene, which was further expanded by the creation of local samba drumming schools (cf. Courteau 2006) and more recently by the strategic branding of Wellington's popular Cuba St Festival as a kind of Latin 'carnival' (Brunt 2010). ${ }^{10}$ In the late 1990s, local Latin dance schools and instructors provided outlets for musical performance, leading to the creation of bands like Orquesta Salvaje, Candela and Son del Monte. For the most part, these ensembles were comprised of talented amateurs and aficionados of Latin music connected to the local dance and drumming scenes. However, their repertoire was limited by the scarcity of Spanish-language singers and Latin American instrumentalists in the local community. This changed in 2003 with the arrival of Cuban guitarist Roberto Rodriguez, who established the group Calle Cuba, which released an independent nine-track album De Aquí ... De Allá (2004) and became a regular fixture at both the Tauranga and Nelson Jazz Festivals. The arrival of Mexican guitarist Carlos Navarette in 2004 and dancer-percussionist Rafael Ferrer Noel in 2005 further augmented the local Latin scene. Together with other Wellington musicians, they formed various other groups between 2004 and 2007, including Los Guagua Boys, Grupo Salsón, Madera Fina, Son Asere, Son Clave and Mariachi Loko.

While these groups largely utilise the same pool of musicians, they differ in repertoire content and size, ranging from full-scale salsa band to intimate acoustic duo. The diversity of band names and identities reflects, on the one hand, the diversity of interests of the various musicians involved in Wellington's Latin music scene, and, on the other hand, the need to clearly identify divergent repertoires in a scene that offers a limited number of venues for live music performance. Not content to operate under a one-size-fits-all label for 'Latin' music, these musicians tailor their band identity according to the repertoire. An example is provided by Navarette:

Mariachi Loko was really just created for the Cuba Street Carnival. We thought a mariachi group would be good at the carnival, so we gave ourselves a new name to do it. It really doesn't operate any other time ...' (Interview with the author, 27 June 2009)

Rodriguez and Ferrer Noel collaborate in Calle Cuba and Los Guagua Boys when they wish to perform generic Afro-Cuban styles such as traditional Cuban son for dance events, but they use their duo Madera Fina as their outlet for 
Rodriguez's original compositions, and both consider this group to be the most musically satisfying of their bands, as Rodriguez relates:

Playing salsa again and again gets a little tiring after a while. It's all the same, never goes anywhere musically. But with Madera Fina I've been able to try my own music ... things I would never have been able to try back in Cuba. In Cuba I was a guitarist and tres player, a chorus singer but not a lead singer. But here [in New Zealand] I often have to sing because there are few other Latino singers who know a wide repertoire of Cuban music. My musician friends in Cuba laugh at me when I tell them I'm singing the lead part [because] I would never have done this back there. (Interview with the author, 27 June 2009)

For the most part, Rodriguez's original compositions follow the Cuban nueva trova tradition and incorporate elements of son and trova alongside culturally de-centred textures of guitar and percussion, with reference to a wide scope of commercial popular music styles.

\section{Conclusion}

Idiosyncratic histories, demographies and performance trajectories combine to produce the unique character of contemporary Latin American music in Australasia, which is reflected in the enduring modes of performance that characterise the local Latin scenes. Andean folkloric ensembles remain prominent in live performances by Latin Americans in Australasia, and their contextualisation as 'world music' or 'indigenous music' consolidates their position in contemporary performance scenes. Commercially successful groups such as Inka Marka have even attempted to align themselves with the more lucrative 'tropical' music and jazz scenes by attempting Andeanised covers of Latin-jazz standards like 'Aqualera do Brasil' and 'Besame mucho', which both appear on their 2005 album Shaman. Meanwhile, Andean instruments continue to play a role in live performance by Latin American migrants outside of the folklore context, as exemplified by contemporary Sydney group Son Veneno's incorporation of charango and Andean flutes in a repertoire that is otherwise centred on Afro-Caribbean styles.

Meanwhile, the social coding of Latin as exotic entertainment endures and is perpetuated by both Latino/a and non-Latino/a exponents, sometimes in selfcontradictory ways. In a recent advertisement, Brisbane ensemble La Gran Salsa were sensationally described as purveyors of 'romantic sultry soulful boleros, Caribbean party music, cha-cha and a lot of red hot spicy salsa'11 performing repertoire by Gloria Estefan, Jennifer Lopez, Ricky Martin, Buena Vista Social Club, Carlos Santana and Tito Puente. Despite this eclectic (and commercially pragmatic) mix of influences, La Gran Salsa's performances are actually informed by expert insider and outsider musicians and deep scholarly engagement with certain Latin American traditions ( $c f$. Varney 2001). Their repertoire selection is a reflection of audience expectations in circumstances where 'Latin' is still considered a homogeneous entertainment music category.

The global mass-mediation of Latin American folkloric and popular music styles that has occurred since the turn of the 21st century has helped to create niches for second generation and new migrant performers unburdened by the exile and oppression experienced by earlier migrants. This is exemplified by the music of groups like Auckland's Batucada Sound Machine (BSM) ${ }^{12}$ - a multi-ethnic festival band who incorporate an impressive range of genres and textures into their performances, including layers of Brazilian street percussion, funk-oriented drum and bass, a 
three-piece horn section and a hip-hop vocalist. While not specifically 'Latin', this hybrid ensemble is nevertheless heavily dependent on Latin American musical influences, and band members include prominent artists such as Ozomatli, Manu Chao and Chico Science among their sources of musical inspiration, demonstrating a broad knowledge of contemporary commercial music from diverse American origins.

Ultimately, all of these influences have contributed to the development of a rich environment for Latin American migrant musicians, their children, and their counterparts from other sectors of Australasian society to engage, share, and develop a localised identity for Latin American music. While mass-mediated forms of Latin American music have had a historical presence in mainstream Australasian popular music, the late 20th century and early 21st century migration of Latin Americans to Australia and New Zealand infused live Latin music with a sense of social purpose. For first-stage migrants of the 1970s and 1980s, this was reflected in musical responses to the political circumstances behind their migration, as well as the challenges posed by adapting to life in their host countries. For their Australasian born children and for second-stage migrants post-2000, the music also reflects the interests and desires of a growing intergenerational and multi-layered community striving for a sense of shared identity and belonging.

\section{Endnotes}

1. See http://www.hispanicfiesta.com.au (accessed 18 May 2010) for further information about this annual event.

2. This article is methodologically grounded in my own ethnographic experience as a freelance trombonist performing in Latin American music contexts in Australia and New Zealand, and over a decade of research engagement with Latin American migrant musicians (see Bendrups 2001, 2003).

3. The terms 'Andean' and 'tropical' can be understood in different ways internationally and require some explanation. For the purposes of this paper, I use these terms in the manner in which they are deployed locally in Australia and New Zealand. In this context, 'Andean' refers to the range of regional indigenous traditions that were transformed into a generic folkloric style by urban Chilean performers (Kurapel 1997, p. 181; Díaz Gomez 2003, p. 395). Meanwhile, 'tropical' refers to an assortment of transnationalised Afro-Caribbean and South American styles performed by Latin American migrants in Australasia including salsa, samba, cumbia, merengue, and others. This usage follows that of Negus (1999, pp. 132-3).

4. While it is not possible to encompass the output and individual life experiences of every Latin American migrant musician here, and while some of these omissions are regrettable, the examples I include have been chosen because of the way they reflect the shared experience of Latin American migrant musicians in Australia and New Zealand.

5. From Te Ara - The Encyclopedia of New Zealand; http://www.TeAra.govt.nz/en/latin-americans/3 (accessed 25 January 2010).
6. See http://www.araucolibre.com/about_us.htm (accessed 25 January 2010).

7. Hobart's Salamanca Market bears no relationship to the Spanish city of Salamanca. Rather, the market is named for the street where it is held, Salamanca Place, which was itself named to commemorate the Duke of Wellington's military victory in the Battle of Salamanca in 1812.

8. See http://www.araucolibre.com/recordings.htm (accessed 25 January 2010).

9. See http://www.inkamarka.com/html/inkaworld. html (accessed 25 January 2010).

10. Wellington's Cuba Street is surrounded by a number of Cuban-themed cafes and restaurants that have been established in the last decade or so, and this, together with the festival, provides a nurturing environment for the performance projects of Latin American musicians and dancers who have settled in Wellington. Cuba Street is named after one of the ships that brought new settlers to Wellington in the 19th century, and while it is located in a part of the inner city that has long hosted an artistic community, it is only recently that local businesses, performers and promoters have begun to develop and assert any kind of connection with Cuban culture.

11. This concert was advertised as part of the 2009 Queensland Academy for Creative Industries concert series; see http://qaci.eq.edu.au/index. php/exhibitions/event/qaci-concert-series/ (accessed 25 January 2010).

12. For more information, see http://www. batucadasoundmachine.com (accessed 25 January 2010). 


\section{References}

Aparicio, F.R., and Jáques, C.F. 2003. 'Introduction', in Musical Migrations: Transnationalism and Cultural Hybridity in Latin/o America, vol. 1, ed. F.R. Aparicio and C.F. Jáques (New York, Palgrave), pp. 1-12

Bendrups, D. 2001. 'Melbourne's Latin American music scene', Perfect Beat, 5/2, pp. 19-29

Bendrups, D. 2003. "'Latin" music and dance since 1970', in The Currency Companion to Music and Dance in Australia, ed. J. Whiteoak and A. Scott-Maxwell (Sydney, Currency House and Currency Press), pp. 393-4

Brunt, S. 2010. 'Sounding out the streets: performance, cultural identity and place in Wellington's Cuba Street Carnival', in Many Voices: Aotearoa/New Zealand Music and National Identity, ed. H. Johnson (Newcastle upon Tyne, Cambridge Scholars Publishing) (pp. 39-49)

Burnley, I.H. 2001. The Impact of Immigration on Australia: A Demographic Approach (Melbourne, Oxford University Press)

Cepeda, M.E. 2000. 'Mucho loco for Ricky Martin; or the politics of chronology, crossover and language within the Latin(o) music boom', Popular Music and Society, 24/3, pp. 55-71

Clark, W.A. 2002. 'Doing the samba on Sunset Boulevard: Carmen Miranda and the Hollywoodization of Latin American music', in From Tejano to Tango: Latin American Popular Music, ed. W.A. Clark (New York, Routledge), pp. 252-76

Courteau, M. 2006. Music and Dance Performance, Longing, and the Construction of Brazil in Auckland, New Zealand, unpublished Masters thesis (Auckland, University of Auckland)

Díaz Gomez, J. 2003. 'Spanish-speaking immigrants' traditions', in The Currency Companion to Music and Dance in Australia, ed. J. Whiteoak and A. Scott-Maxwell (Sydney, Currency House and Currency Press), pp. 394-7

Eisentraut, J. 2001. 'Samba in Wales: making sense of adopted music', British Journal of Ethnomusicology, 10/1, pp. 85-106

Fairley, J. 1989. 'Analysing performance: narrative and ideology in concerts by ¡Karaxu!', Popular Music, 8/1, pp. 1-30

Fairley, J. 2000. 'Andean music', in The Rough Guide to World Music, vol. 2: Latin and North America, Caribbean, India, Asia and the Pacific, ed. S. Broughton and M. Ellingham (London, Rough Guides), pp. 273-88

Garrido, W. 2009. 'Re-inventing the Latin wheel: the hybridisation of Chilean music transplanted in Australia a case study', paper presented at 'What's it Worth?' 'Value' and Popular Music. 2009 Conference of the Australia/New Zealand chapter of the International Association for the Study of Popular Music, University of Auckland, 27-29 November

Hardie, R., and A. Thomas. 2009. 'Introduction', in Jazz Aotearoa: Notes Towards a New Zealand History, ed. R. Hardie and A. Thomas (Wellington, Steele Roberts), pp. 7-13

Hosokawa, S. 1999. "Salsa no Tiene Frontera": Orquesta de la Luz and the globalization of popular music', Cultural Studies, 13/3, pp. 509-34

Hosokawa, S. 2002. 'Salsa No Tiene Fronteras: Orquesta de la Luz and the globalization of popular music', in Situating Salsa: Global Markets and Local Meaning in Latin Popular Music, ed. L. Waxer (New York and London, Routledge), pp. 289-312

Knudsen, J. 2001. 'Dancing cueca "with your coat on": the role of traditional Chilean dance in an immigrant community', British Forum for Ethnomusicology, 10/2, pp. 61-83

Kurapel, A. 1997. Margot Loyola: La Escena Infinita del Folklore (Santiago, Fondart)

Macías, A. 2003. 'Rock con Raza, Raza con Jazz: Latinos/as and post-World War II popular American music', in Musical Migrations: Transnationalism and Cultural Hybridity in Latin/o America, vol. 1, ed. F. Aparicio and C. Jáques (New York, Palgrave), pp. 183-98

Manuel, P. 1995. Caribbean Currents: Caribbean Music from Rumba to Reggae (Philadelphia, Philadelphia University Press)

Mayne, A. 1989. 'What immigration policy for Australia: an historical perspective', Overland, 115

Negus, K. 1999. Music Genres and Corporate Cultures (New York, Routledge)

Pacini Hernandez, D. 2003. 'Amalgamating musics: popular music and cultural hybridity in the Americas', in Transnationalism and Cultural Hybridity in Latin/o America, vol. 1, ed. F.R. Aparicio and C.F. Jáques (New York, Palgrave), pp. 13-32

Pacini Hernandez, D. 2010. Oye Como Va! Hybridity and Identity in Latino Popular Music (Philadelphia, Temple University Press)

Román-Velázquez, P. 2002. 'The making of a Salsa music scene in London', in Situating Salsa: Global Markets and Local Meaning in Latin Popular Music, ed. L. Waxer (New York and London, Routledge), pp. 259-88

Rondón, C.M. 2008. The Big Book of Salsa: A Chronicle of Urban Music from the Caribbean to New York City (Chapel Hill, University of North Carolina Press)

Ryan, M. 1998. 'Latin Americans and Caribbeans', in The Garland Encyclopedia of World Music, vol. 9: Australia and the Pacific Islands, ed. A. Kaeppler and J. Love (New York, Garland Publishing), pp. 82-4

Salazar, M. 2002. Mambo Kingdom: Latin Music in New York (New York, Schirmer)

Shain, R.M. 2002. 'Roots in reverse: Cubanismo in twentieth-century Senegalese music', International Journal of African Historical Studies, 35/1, pp. 83-101

Varney, J. 2001. 'An introduction to the Colombian "Bambuco"', Latin American Music Review/Revista de Música Latinoamericana, 22/2, pp. 123-56 
Wade, P. 1998. 'Music, blackness and national identity: three moments in Colombian history', Popular Music, 17/1, pp. 1-19

Whiteoak, J. 2003. 'Latin American influences', in The Currency Companion to Music and Dance in Australia, ed. J. Whiteoak and A. Scott-Maxwell (Sydney, Currency House and Currency Press), pp. 393-394

Whiteoak, J. 2008. "Play Gypsy to Me": Australian imaginings of "Gypsies" in popular music before multiculturalism and "world music", in Whose Popular Music? Industry, Performers, Fans: Selected Proceedings from the 2006 IASPM Australia/New Zealand Conference, ed. I. Collinson (Sydney, IASPM-ANZ), pp. 16-25

Whiteoak, J. 2009. 'Kookaburra Samba: mainstream and non-mainstream interpretations of Hispanic music and dance in pre-multicultural Australia', in Stuck in the Middle: The Mainstream and its Discontents Selected Proceedings of the 208 IASPM-ANZ Conference, ed. C. Strong and M. Phillipov (Auckland, IASPM-ANZ), pp. 12-21

Wilson, J. 2009. 'Latin Americans - immigration history', in Te Ara - the Encyclopedia of New Zealand. http:// www.TeAra.govt.nz/en/latin-americans/1://www.TeAra.govt.nz/en/latin-americans/1 (accessed 2 October 2009)

Wyndham, M., and P. Read. 2003. 'Buena Vista Social Club: local meets global and lives happily ever after', Cultural Geographies, 10, pp. 498-503

\section{Discography}

Alymayu, Latitud '0. Independent release. 2008

Arauco Libre, Mapuche. Independent release. 2006

Calle Cuba, De Aquí ... De Allá. Independent release. 2004

Gipsy Kings, Gipsy Kings. Columbia, WCK 90919. 1987

Inka Marka, Auki Auki. Black Market Music, BMM 231.2. 1999

Inka Marka, Shaman. Black Market Music, BMM 299.2. 2005

Kantuta, Kantuta. EMI, 7997562. 1992

Kantuta, Fiesta: The Ultimate Latin Dance Album - Salsa Merengue Dance Party. Ocarina Records. 1997

Tropical Dreams, Party with La Cucaracha. Independent release. 1998 